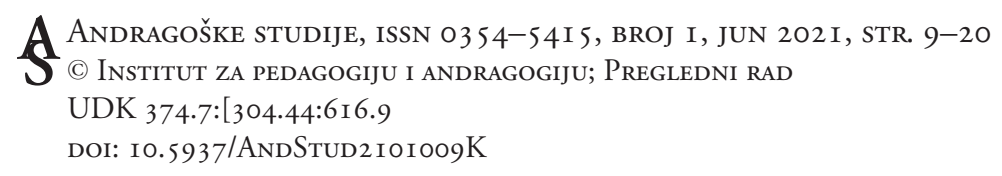

George A. Koulaouzides ${ }^{1}$

Hellenic Open University, Greece

\title{
The COVID-19 Crisis as a Collective Biographical Disjuncture: Understanding the Pandemic as a Learning Experience
}

\begin{abstract}
This paper examines the COVID-19 pandemic as a disorienting social experience and as an opportunity to engage in learning processes that may critically examine the dysfunctional assumptions that have consequentially emerged from it. The first part of the paper based on the theoretical perspectives of Peter Jarvis develops a framework for the definition of a social experience as a collective biographical disjuncture. Based on that definition, the paper exposes the assumptions that have been challenged during the pandemic era in the areas of social interaction, education, and employment. Finally, the paper argues that critical learning may provide to adults with the necessary cognitive "antibodies" to overcome the side-effects of the pandemic in our social life in the postpandemic period.
\end{abstract}

Key words: critical adult learning, biographical disjuncture, COVID-19.

\section{Introduction}

The COVID-19 pandemic has proven to be something more than the widespread growth of a highly contagious disease with a significant mortality potential. In order to prevent the consequences of the pandemic, a series of measures (e.g., curfews, quarantines, etc.) were taken by governments all over the world, and their implementation caused many disjunctures in many aspects of our social life. New realities have emerged, and new meaning making processes are needed to respond to them adequately. In the following sections of this paper, I will present the notion of the collective biographical disjuncture in order to argue that the pandemic of COVID-19 may be classified as such. Next, I will briefly refer to the main assumptions that to my understanding were challenged by the pandemic in

\footnotetext{
${ }^{1}$ George A. Koulaouzides, PhD is Assistant Professor at the Hellenic Open University, Greece
} (gkoulaouzidis@eap.gr). 
the areas of education, employment, and social interaction. Finally, I will present an informed understanding of critical adult learning as a process of restoring the disharmonies caused by this novel global disjuncture.

\section{Collective Biographical Disjunctures as Adult Learning Triggering Events}

The lengthy academic dialogue on the differences between learning in childhood-adolescence and adulthood came close to an end soon after Jack Mezirow published his unique work on transformative learning (Mezirow, 1991). Following Mezirow's contribution many other researchers and scholars argued in favour of this distinction presenting additional supporting reasons, such as the nature of experience (Merriam, 2001), the nature of critical thinking in adulthood (Brookfield, 2000), differences in adult identity development (Illeris, 2007) and differences in adult intelligence and cognition (Tennant, 2006). On the other hand, there were also voices that contrasted this distinction by supporting the idea that there is no significant difference in adult learning processes per se and reoriented the discussion claiming that the main difference is located at the adult teaching procedures (e.g., Rogers 2003). To my understanding this debate was more or less terminated after Jarvis (2009) presented his influential work titled "Learning to be a Person in Society" where he established a holistic learning theory that described the complex phenomenon of learning as an existential process of becoming a social human being. In brief, Jarvis (2009) considers learning as a process of growth and development in relationship with other human beings and the environment. Learning is considered as a meaning making process which is facilitated through social interaction. Through interaction, a process of being and becoming, our experiences and their recognized content are transformed and integrated into our biographical reservoir. The result of this on-going learning process, which may be unconscious, pre-conscious, or conscious, is a person who experiences an uninterrupted process of change that is affecting both the person itself and society at large.

However, learning is not an accidental process, something that just happens. On the contrary, there is always something that triggers learning, an initiation event which may be a cognitive experience or an emotional situation or in some cases both. Jarvis (2012) defines this event as "disjuncture" and describes it in general terms as "the gap between our biography and our perception of our experience" (p. 13). This event has also been recognized within the theory of transformation with the term "disorienting dilemma" and several transformative 
learning scholars have offered interesting elaborations of its nature (e.g., Mälkki, 2012; Laros 2017). Nevertheless, it is the description of Jarvis (2011) that illuminates the complex and multidimensional nature of disjuncture. According to his view, a biographical disjuncture that triggers a meaning making learning process may be described as follows:

It can occur as a slight gap between our biography and our perception of the situation, to which we can respond by slight adjustments in our daily living - a gap we hardly notice since it occurs within the flow of time. It can also occur with larger gaps that demand considerable learning, even to the extent of studying courses and disciplines and embarking on self-directed projects. In the meeting of strangers, the disjuncture might not only occur in the discourse between them, but it might actually occur between them as persons and their cultures, and it takes time for the stranger to be received and a relationship, or harmony, to be established. In addition, some disjunctural situations - often emotive in nature - just cause us to wonder at the beauty, pleasure and so forth that we are experiencing. In these situations, it is sometimes impossible to incorporate our learning from them into our biography and our 'taken-for-granted'. These are what we might call 'magic moments' to which we look forward in the hope of repeating them in some way or other but upon which we might often reflect. (Jarvis, 2011, p. 25)

From the above it is apparent that the notion of disjuncture is quite well described and presumably understood on the individual level. However, the level of clarity is not the same when it comes to a collective or a shared disjuncture although there are efforts that have attempted to describe its features in the framework of the current pandemic (i.a., Romano, 2020). Since every person understands the world within the limits that are set by the cultural frame of reference where she/he acts and interacts, the collectiveness of a disjunctural experience becomes complicated especially when this collectiveness is extended beyond the borders of a specific culture.

Therefore, to my opinion and in an effort to generate a functional definition, a collective biographical disjunctural experience has to have at least the following features: (a) to be able to generate within a certain period of time a concurrent universal gap between the individual biography of every person in a society and an existing and unchallenged certainty, (b) to have the potential for a shared comprehension that is not affected by the different meaning schemes 
and perspectives that create individual truths, (c) to be able to provoke a universal compelling dialogue that has the dynamic needed to penetrate isolation and estrangement and (d) to have the potential to initiate collective learning actions towards the restoration of the disharmony created by the aforementioned gap.

In the present century there are two events that seem to have the characteristics of a collective disjuncture. The first was the worldwide Great Recession that started in 2007 in the U.S. and amazingly quickly became a multinational financial crisis that severely affected the national economies of many countries for over a decade, leading to sudden reforms, austerity measures, impoverishment, and humanitarian crisis (Johnston, 2011). The second is the existing COVID-19 pandemic that was first identified in the end of 2019 in China. As of May $30^{\text {th }}$, 2021, more than 171 million cases have been confirmed and more than 3.5 million deaths have been attributed to COVID-19, making it one of the deadliest pandemics in the history of humankind.

The aforementioned undisputed realities, and especially the pandemic, created on a global scale a mixture of disorienting emotions of fear, frustration and anger, generated individual as well as social confusion since many taken for granted social practices of our everyday life were unexpectedly altered with measures imposed by national or supranational authorities, and radically challenged many essential and unchallenged assumptions about life in almost every society of the world. In the next paragraphs, I will describe briefly how COVID-19 has challenged a series of assumptions in certain aspects of our social life.

\section{COVID-19 as a Collective Biographical Disjuncture: Assumptions and Realities}

COVID-19 as a collective biographical disjuncture may be experienced through two distinctive ways, either subjectively or through some form of mediation (Jarvis, 2004). A subjective or primary experience involves being infected by the disease or being closely attached to someone who has been infected. A mediated or secondary experience may be linguistic or communicative and involves reading or listening about the pandemic or even being affected by the social consequences of the disease. In both ways, people are faced with an event that generates a disharmony in their taken for granted life. While the disharmony affects many areas of human social life in the following paragraphs, I will focus on the challenged fundamental assumptions that relate to social interaction, education, and work life. 


\section{Social interaction: challenged assumptions and new realities}

Human beings live in relationship (Jarvis, 2009). We are born in relationship, and we grow and develop in connection with others and our social environment. Through interaction and agency, we create knowledge and relationships, and we reinvent our culture (Ratner, 2000). Our assumptions about social interactions are deeply affected by the COVID pandemic. Terms like curfew, quarantine, confinement that were considered distant practices of exceptional situations became suddenly part of our reality. For almost a year now, people in many countries have to declare (through SMS) their intention to leave their home and in many cases use special signed permissions in order to reach their workplace. Taken for granted social activities like participation in life moments (e.g., weddings, birthdays, memorial services, graduation ceremonies) are no longer part of our life. Person to person interaction has been harshly replaced with computer-mediated means of communication. Usual social routines that contribute to the critical process of socialization like going to school or participating in cultural and athletic activities or even gathering in large groups for discussion are substituted with web-based platforms with ambivalent effectiveness as far as emotional development is concerned (Sherman, Michikyan \& Greenfield, 2013).

\section{Education: challenged assumptions and new realities}

Education is not always responding adequately to the changes in society. However, to a greater or lesser extent a common assumption is that education contributes to the alleviation of social inequalities because it acts as a means of transition to the labour market but also contributes to personal fulfilment (Walker et al., 2019). The unforeseen disruption of the educational process at almost every level due to COVID-19 creates conditions that challenge the previous assumption. The relocation of the school environment to the home environment raises questions regarding the assumption about the contribution of education to the alleviation of social inequalities. Pensiero, Kelly, \& Bokhove (2020) have noted in their UK-based research that:

The transition to distance schooling is likely to exacerbate inequalities by socio-economic groups due to both the socio-economic gap in the volume of schoolwork completed and to the relative ability or inability of some parents to support children's learning. Families with a service class background have the twofold advantage of being 
better able to assist their children with home-schooling and of hav-

ing more time to do it as they are more likely to be working from home (p. 19).

Moreover, the rapid application of distance education methods without the relevant curriculum design modifications, the absence of training provisions for educators on the special demands of distance learning as well as the ambiguous fairness in the provision of the necessary technical infrastructure for students (access to computers, laptops, and fast internet connections) are elements that challenge the assumption about the role of education as means for the promotion of social equality (Murat \& Bonacini, 2020).

Promoting participation in vocational education at all educational levels (secondary, post-secondary and tertiary) is supported by the assumption of an easiest entry into the labour market. One of the elements that contributes to this transition is the implementation of programs that foster the attainment of work experience like internships or apprenticeships (Aivazova, 2013). Indeed, the European Union has invested heavily in such programs in the context of promoting the development of skills that may enhance youth employability but also contribute to the development of employment skills of adults who participate in reskilling and upskilling training programs. However, the COVID-19 response measures have overturned these strategies and their consequent assumptions. A large number of companies suspended or cancelled their participation in internship and apprenticeship programs, resulting in the postponement of the process of transition from education life to work life for a large number of trainees (Hurley, 2020). This postponement has consequences especially for those social classes that invest in education and especially in vocational education in order to improve the conditions of their lives.

\section{Employment: challenged assumptions and new realities}

The rise of unemployment due to the measures taken to deal with the coronavirus was anticipated. The closure of both retail and service-oriented businesses had a devastating effect on the employment of a large number of permanent and temporary employees (Pouliakas \& Branka, 2020). In countries where the economy is primarily based on tourism and the related services, unemployment rates have risen while wealth and growth rates have shrunk (Fana, Pérez, \& FernándezMacías, 2020). These phenomena are not unprecedented since they have been observed during other economic or humanitarian crises as well. However, in the case of the pandemic we have additional issues. First, the economic crisis of the 
pandemic manifested itself in the aftermath of the Great Recession mentioned above. This continuum seems to affect a specific age group of the population (adults around the age of 30) who during this prolonged period of instability continuously and unwillingly delayed their transition to social roles that are important for their adult identity. The taken for granted idea of a horizontal effect of an economic crisis on all age groups of the active population is now questionable and requires new forms of management (Tamesberger \& Bacher, 2020).

One of the most important assumptions in the field of career counselling is related to the role of community networks in finding employment opportunities (MacKenzie, Ciupijus, \& Forde, 2019). The physical distancing and the imposed curfews came to challenge this assumption since community networks becomes stronger and more efficient through physical presence. In addition, the pandemic seems to create even greater diversity in the area of gender discrimination in employment opportunities. Women at such times tend to take on caring roles for family members who become infected, and this socially strong stereotypical role may turn out to be an impediment to women's employability and in the end negatively affect years of hard work dedicated to achieving gender employment equality and women's social emancipation (Carli, 2020; Reichelt, Makovi \& Sargsyan, 2021).

Moreover, new inequalities occurred due to the tendency of older adults to be more sensitive to the consequences of COVID-19 infection. This unique epidemiological characteristic of the pandemic formed a double entrance impediment for entering the labour market: young adults who are more resistant to infection do not have the opportunity to enter the labour market due to the closure of many businesses that typically hire younger people (e.g. the services sector), while older adults who have work experience and have invested in reskilling/ upskilling activities to regain or improve their position in the labour market are more susceptible to COVID-19 health consequences and therefore have become a less appealing recruitment option (Monahan, et al., 2020).

As we have seen from this brief presentation, there are several fundamental assumptions that are challenged from the COVID-19 pandemic. While other areas of our social life are also significantly affected (e.g., the health and welfare sector, the art and creative industry sector), my presentation was focused on the areas of social interaction, education, and employment. Though the advances of medical and pharmaceutical research have managed to invent and produce efficient and effective vaccines that will contribute soon to the prevention of the pandemic, the issue that should also be of our concern, as educators, is what kind of learning actions should we employ to restore the disharmonies that were created by the COVID-19 in the aforementioned areas (Tovstiga \& Tovstiga, 2020). 
In my opinion, all these learning actions should include a critical dimension since the emerged realities described above contain new or renewed social inequalities. Therefore, in the next section I will present an understanding of critical adult learning that may serve us in coping with the multiple challenges of individual and social assumptions that have occurred in the current circumstances.

\section{A Well-known and Widely Approved "Vaccine": Critical Adult Learning}

Critical adult learning is one of the most popular terms in the literature of adult education. Most of the influential thinkers of our field have stressed the significance of critical approaches in adult education activities. There are many views on the content and the processes of critical adult learning. For Mezirow (1991) critical learning in adulthood is related with the assessment of the premises of our meaning perspectives while for Fleming (2008) critical adult learning is about imagining, and theorizing "how the cultures and societies in which we live, interact with, and influence the ways in which people relate to each other" (p. 50). Finally, Brookfield \& Holst (2011) suggest that critical learning in adulthood should be about a process that uncovers ideological manipulations. Trying to combine the above and other views on critical learning, I have suggested that a learning process in adulthood is critical when its purpose is to lead the learner in a careful, insightful, and in-depth examination of the assumptions on which our perception of reality is constructed (Koulaouzides, 2017).

However, in view of the disharmonies caused by the pandemic and the challenged assumption that I presented above, I now understand critical adult learning as a form of reflective learning that allow us to recognize and comprehend in depth our assumptions about our relationship with each other and the world (since the pandemic has altered our social interaction meaning-making assumptions); associate the premises of our assumptions to ideological perceptions and challenge the inherent inequalities (realize how our ideologies influence our challenged assumptions, create impediments in fostering change and enhance the development of new or the revival of old inequalities); realize the new realities and the new power relations (understand how specific social elites are benefited from the new relations that develop silently during this period); re-imagine a new understanding about our role as persons in relationship (realize the importance of being in relationship, the consequent solidarity and the needed collective action) and take action to realize this new understanding (engage in collective social learning and action). 


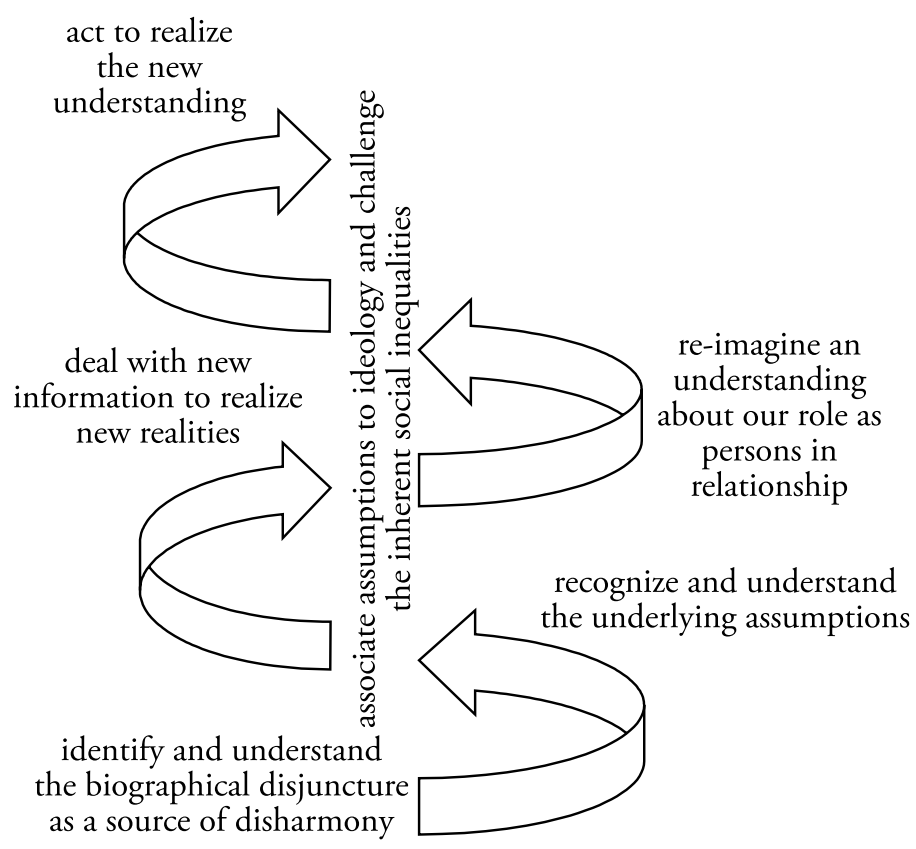

Figure 1. A critical adult learning spiral in the post-pandemic period

Formal, non-formal and informal learning opportunities that engage adults in a spiral of critical thinking like the one depicted in Figure 1, are likely to provide with the necessary cognitive "antibodies" to overcome the side-effects of the pandemic in our social life in the post-pandemic period which seems to be about to start in the near future.

\section{Conclusion}

The pandemic of COVID-19 caused a severe disharmony between our biography and reality making it the perfect example of a collective biographical disjuncture. For almost a year now many of our taken for granted assumptions were challenged in all areas of our social life. New realities have emerged in areas such as our social interaction practices, education, and work life. During the pandemic, a series of measures were devised to prevent the spread of the disease. These measures were mainly directives, orders, and regulations that were imposed on people—a kind of forced instrumental learning process—without any further effort to support people in a critical way during the implementation period. Someone 
may claim that it was of no surprise that these measures had limited success since after the initial good results people were returning to their old understandings, to their old frame of reference about reality, facilitating thus unwillingly new pandemic cycles.

Although there is a collective hope that after the vaccination programs, there will be a gradual return to our pre-pandemic world, some realities that were changed during the pandemic will remain. A thorough understanding of these new realities has to be achieved. A reflective dialogical process that may reveal our assumptions, recognize these new realities, re-imagine our new roles - and at the same time, foster our challenging of the new inequalities and taking action to confront new power relations-may prove of immense value in restoring the disharmony caused by the pandemic.

\section{References}

Arvazova, N. (2013). Role of Apprenticeships in combating youth unemployment in Europe and the United States. Policy Brief, PB13-20. Washington, DC: Peterson Institute for International Economics.

Brookfield, S. D. (2000). The concept of critically reflective practice. In A. L. Wilson \& E. R. Hayes (Eds.), Handbook of adult and continuing education (pp. 33-49). San Francisco: Jossey-Bass.

Brookfield, S. D., \& Holst, J. D. (2010). Radicalizing learning: Adult education for a just world. San Francisco: Jossey-Bass.

Carli, L.L. (2020). Women, Gender equality and COVID-19. Gender in Management, 35(7/8), 647-655.

Fana, M., PÉrez, S. T., \& Fernández-Macías, E. (2020). Employment impact of Covid-19 crisis: from short term effects to long terms prospects. Journal of Industrial and Business Economics, 47(3), 391-410.

Fleming, T. (2008). A Secure Base for Adult Learning: Attachment Theory and Adult Education. Adult Learner: The Irish Journal of Adult and Community Education, 25, 33-53.

Hurley, P. (2020). The impact of coronavirus on apprentices and trainees. Mitchell Institute for Education and Health Policy, Victoria University. Retrieved from www. mitchellinstitute.org.au

Illeris, K. (2007). How we learn: Learning and non-learning in school and beyond. London: Routledge.

Jarvis, P. (2004). Adult Education \& Lifelong Learning. London: Routledge Falmer.

Jarvis, P. (2009). Learning to be a Person in Society. London: Routledge.

Jarvis, P. (2011). Learning from Everyday Life. In P. Jarvis (Ed.), The Routledge International Handbook of Lifelong Learning (pp. 19-30). London: Routledge. 
Jarvis, P. (2012). An Analysis of Experience in Human Learning. Recherche et formation, $70,15-30$.

Johnston, S. (2011). A Golden Age for Adult Education: The Collective Disorienting Dilemma. College Quarterly, 14(4), Retrieved from https://files.eric.ed.gov/fulltext/EJ967639.pdf.

Koulaouzides, G. (2017). Critical Reflection and Empowerment in Adult Education Practice. In G. Koulaouzides \& K. Popovic (Eds.), Adult Education \& Lifelong Learning in Southeastern Europe (pp. 17-26). Rotterdam: Sense Publishers.

Laros, A. (2017). Disorienting dilemmas as a catalyst for transformative learning. In A. Laros, T. Fuhr, \& E. W. Taylor (Eds.), Transformative learning meets bildung: An International Exchange (pp. 85-95). Rotterdam, Netherlands: Brill Sense.

MacKenzie, R., Ciupijus, Z., \& Forde, C. (2019). Kinship and community networks. In G. Gall (Ed.), Handbook of the politics of labour, work and employment. Cheltenham, Northampton: Edward Elgar Publishing.

MäLkki, K. (2012). Rethinking Disorienting Dilemmas Within Real-Life Crises: The Role of Reflection in Negotiating Emotionally Chaotic Experiences. Adult Education Quarterly, 62(3), 207-229.

Merriam, S. B. (2001). Andragogy and Self-Directed Learning: Pillars of Adult Learning Theory. New Directions for Adult and Continuing Education, 89, 3-12.

Mezirow, J. (1991). Transformative Dimensions in Adult Learning. San Francisco: JosseyBass.

Monahan, C., Macdonald, J., Lytle, A., Apriceno, M., \& Levy, S. R. (2020). COVID-19 and ageism: How positive and negative responses impact older adults and society. American Psychologist, 75(7), 887-896.

Murat, M., \& Bonacini, L. (2020). Coronavirus pandemic, remote learning and education inequalities (No. 679). GLO Discussion Paper. Retrieved from

Pensiero, N., Kelly, A., \& Bokhove, C. (2020). Learning inequalities during the Covid-19 pandemic: how families cope with home-schooling. University of Southampton. Retrieved from https:/www.southampton.ac.uk/publicpolicy/covid19/ learning-inequalities-covid-19.page

Pouliakas, K., \& Branka, J. (2020). EU Jobs at Highest Risk of Covid-19 Social Distancing: Will the Pandemic Exacerbate Labour Market Divide? IZA Discussion Paper No. 13281, Retrieved from: https://ssrn.com/abstract=3608530.

Ratner, C. (2000). Agency and culture. Journal for the Theory of Social Behaviour, 30(4), 413-434.

Reichelt, M., Makovi, K., \& Sargsyan, A. (2021). The impact of COVID-19 on gender inequality in the labor market and gender-role attitudes, European Societies, 23(1), 228-245.

Rogers, A. (2003). What is the difference? A new critique of adult learning and teaching. Leicester: NIACE.

Romano, A. (2020). The Pandemic Emergency as a Collective Disorienting Dilemma. Italian Journal of Health Education, Sports \& Inclusive Didactics, 4(4), 77-89. 
Sherman, L. E., Michikyan, M., \& Greenfield, P. M. (2013). The effects of text, audio, video, and in-person communication on bonding between friends. Cyberpsychology: Journal of Psychosocial Research on Cyberspace, 7(2).

Tamesberger, D., \& Bacher, J. (2020). COVID-19 Crisis: How to Avoid a 'Lost Generation'. Intereconomics 55, 232-238.

Tennant, M. (2006). Psychology and adult learning. London: Routledge.

Tovstiga, N., \& Tovstiga, G. (2020). COVID-19: a knowledge and learning perspective. Knowledge Management Research \& Practice, 1-6.

Walker, J., Pearce, C., Boe, K., \& Lawson, M. (2019). The Power of Education to Fight Inequality: How increasing educational equality and quality is crucial to fighting economic and gender inequalities. Oxfam International. Retrieved from https:// oxfamilibrary.openrepository.com/handle/10546/620863.

George A. Koulaouzides ${ }^{2}$

Helenski otvoreni univerzitet, Grčka

\section{Kriza usled pandemije kovida 19 kao kolektivna biografska disjunkcija: tumačenje pandemije kao prilike za učenje}

Apstrakt: U ovom radu ćemo razmotriti dezorijentišuće socijalno iskustvo koje je nastalo kao posledica pandemije kovida 19 i sagledaćemo je kao priliku za upuštanje u proces učenja u kojem se mogu kritički ispitati disfunkcionalne pretpostavke koje su posledično proizašle iz ove pandemije. Prvi deo rada se zasniva na teoretskim perspektivama Pitera Džarvisa i njime uspostavljamo okvir za definisanje socijalnog iskustva kao kolektivne biografske disjunkcije. $\mathrm{Na}$ osnovu utvrđene definicije, u ovom radu dalje sagledavamo pretpostavke u oblasti socijalne interakcije, obrazovanja i zaposlenja koje su preispitane u vreme pandemije. Konačno, iznosimo stav da kritičko učenje odraslima može da obezbedi neophodna kognitivna „antitela“ pomoću kojih će moći da se izbore sa neželjenim dejstvima pandemije u društvenom životu u poslepandemijskom periodu.

Ključna reč: kritičko učenje odraslih, biografska disjunkcija, kovid 19.

\footnotetext{
${ }^{2}$ Dr George A. Koulaouzides je docent na Helenskom otvorenom univerzitetu, Grčka.
} 